\title{
PENDIDIKAN KEWARGANEGARAAN SEBAGAI PENDIDIKAN KARAKTER DI PERSEKOLAHAN
}

\author{
Rinita Rosalinda Dewi ${ }^{1}$, Edi Suresman ${ }^{2}$, Cik Suabuana ${ }^{3}$ \\ ${ }^{1}$ Universitas Pendidikan Indonesia \\ rinitarosalindadewi@upi.edu \\ ${ }^{2}$ Universitas Pendidikan Indonesia \\ 2 esuresman@upi.edu \\ ${ }^{3}$ Universitas Pendidikan Indonesia \\ suabuana_cik@yahoo.co.id
}

\begin{abstract}
ABSTRAK
Penelitian ini bertujuan untuk mengetahui bagaimanakah Implementasi Pendidikan Kewarganegaraan sebagai sebagai Pendidikan Karakter di Persekolahan khususnya di SDN 077 Sejahtera, Bandung. Adapun fokus penelitian pada karakter religius, semangat kebangsaan, rasa ingin tahu, tanggung jawab, bersahabat/komunikatif dan kerja keras. Penelitian ini menggunakan metode kualitatif deskrptif analitis. Instrumen yang digunakan observasi, wawancara, dan studi dokumentasi. Hasil penelitian ini menunjukkan bahwa (1) perencanaan implementasi pendidikan keawarganegaraan sebagai pendidikan karakter di persekolahan khususnya di SDN 077 Sejahtera telah disiapkan dalam perencanaan pembelajaran yaitu dalam silabus dan RPP berkarakter. (2) pelaksanaan implementasi pendidikan kewarganegaraan sebagai pendidikan karakter di persekolahan khususnya di SDN 077 Sejahtera yaitu guru PKn telah menerapkan dan menggunakan metode dan sumber belajar yang beragam serta mengintegrasikan berbagai karakter dalam kegiatan. (3) Evaluasi implementasi pendidikan kewarganegaraan sebagai pendidikan karakter di persekolahan khususnya di SDN 077 Sejahtera yaitu guru telah melakukan berbagai penilaian seperti tes tulis, tetapi masih kurang maksimal dalam melakukan penilaian terhadap sikap peserta didik selama proses pembelajaran. (4) Kendala implementasi pendidikan kewarganegaraan sebagai pendidikan karakter di persekolahan khususnya di SDN 077 Sejahtera adalah waktu pembelajaran dianggap sangat cepat, sehingga penilaian terhadap sikap siswa kurang optimal, dan pendidikan karakter dirumah yang kurang, sehingga pendidikan karakter di sekolah juga kurang optimal.
\end{abstract}

Kata kunci: Pendidikan kewarganegaraan; Pendidikan karakter; Sekolah 


\section{ABSTRACT}

This study aims to determine how the implementation of civic education as character education in schools, especially at SDN 077 Sejahtera, Bandung. The research focus is on religious character, national spirit, curiosity, responsibility, friendly/ communicative, and hard work. This study used a qualitative descriptive-analytical method.The instruments used were observation, interview, and documentation study. The results of this study indicate that (1) Planning the implementation of civic education as character education in schools, especially SDN 077 Sejahtera, has been prepared in learning planning, namely in syllabus and character lesson plans. (2) The implementation of civic education as character education in schools, especially at SDN o77 Sejahtera, namely Civics teachers have implemented and used various learning methods and resources and integrated various characters in activities. (3) Evaluation of the implementation of civic education as character education in schools, especially at SDN 077 Sejahtera, namely the teacher has carried out various assessments such as written tests but is still not maximal in assessing the attitudes of students during the learning process. (4) The constraints on the implementation of civic education as character education in schools, especially at SDN 077 Sejahtera are that learning time is considered very fast so that the assessment of student attitudes is not optimal, and character education at home is lacking, so that character education in schools is also less than optimal.

Keywords: Civic Education; Character Education; School

\section{PENDAHULUAN}

Abad ke-21 merupakan abad kebudayaan dan pendidikan (Zakiyah dan Rusdiana, 2014, hlm. 59) yang ditandai dengan ketersediaan informasi yang mudah diakses, teknologi canggih, masyarakat yang berubah dengan cepat, serta daya saing yang tinggi. Dari sekian banyak perubahan yang terjadi, setidaknya ada beberapa yang permanen dan disepakati semua negara di dunia bahwa pendidikan memiliki dua tujuan utama, pertama membantu siswa menjadi lebih pintar, dan yang kedua membantu siswa menjadi lebih baik (Lickona, 2012, hlm. 5). Semakin majunya peradaban di abad ini, maka guru dan peserta didik sebagai salah satu komponen dalam pendidikan dituntut untuk memiliki kemampuan belajar abad 21.

Menurut BSNP (2010), tantangan yang dihadapi pendidikan pada abad ke21 antara lain keterampilan berpikir kritis dan pemecahan masalah, keterampilan komunikasi dan kolaborasi, keterampilan kreativitas dan pembaharuan, literasi teknologi informasi dan komunikasi, keterampilan pembelajaran kontekstual, serta keterampilan literasi informasi dan media. Dengan menghadapi tantangan 
pendidikan di abad ke-21 ini, akan mendorong terwujudnya cita-cita negara Indonesia yakni sejahtera dan bahagia dengan membentuk masyarakat yang terdiri dari sumber daya manusia yang berkualitas, yaitu individu yang mandiri dan berkemauan, sehingga dapat mewujudkan cita-cita negara serta setara dengan negara lain di dunia (Haryanto, 2019). Tetapi kenyataannya sistem pendidikan di Indonesia belum mampu menghadapi kondisi tantangan pendidikan abad 21 . Hal ini terlihat dari masih berjalannya model pembelajaran satu arah di sebagian besar sekolah, sehingga membuat siswa hanya mengetahui dan mendengarkan penjelasan guru. Keadaan lain terlihat dari kebiasaan siswa yang kurang kreatif, kurang kemampuan berinovasi, memiliki kemampuan pemecahan masalah yang buruk, dan tidak terbiasa dengan komunikasi dua arah (Lydiasari, 2018).

Permasalahan lain dalam pendidikan abad 21 khusunya yang dialami oleh guru yaitu penanaman pendidikan karakter karena tugas guru bukan untuk mencerdaskan peserta didik saja tapi bagaimana mentransformasi mereka menjadi pribadi yang bertaqwa, pribadi yang berintegritas, pribadi yang disiplin, pribadi yang kreatif dan memiliki rasa ingin tahu, serta pribadi yang terus bersemangat dan terus menghargai orang lain (Nuraini, 2019). Pendidikan didefinisikan sebagai upaya sadar dan terencana yang bertujuan untuk mengembangkan potensi siswa dan menjadikan mereka manusia yang lebih baik (Sauri, \& Budimansyah, 2014, hlm. 24; Sauri, \& Nurdin 2019, hlm. 34). Selain itu, pendidikan juga berfungsi untuk mengembangkan kemampuan, membentuk kepribadian, dan mewujudkan peradaban bangsa yang bermartabat serta mencerdaskan kehidupan bangsa. Makna pendidikan bermartabat disini adalah menumbuhkembangkan potensi peserta didik dan menjadikan mereka orang yang beriman dan bertakwa kepada Tuhan Yang Maha Esa, berakhlak mulia, sehat, berilmu, cakap, kreatif, mandiri, serta menjadi warga negara yang demokratis dan bertanggung jawab (Prasetyo \& Marzuki, 2016, hlm. 215-216). Sedangkan karakter adalah nilai unik dalam karakter, moralitas dan kepribadian, yang dibentuk melalui internalisasi berbagai kebijakan yang dipertimbangkan dan digunakan sebagai cara observasi, pemikiran, perilaku, percakapan dan perilaku dalam kehidupan sehari-hari (Wahyu, 2011, hlm. 141; Putra, 2017, hlm.49). Sehingga dapat disimpulkan bahwa pendidikan karakter adalah upaya sadar dan terencana melalui lingkungan belajar yang bertujuan untuk mendorong tumbuh kembang segenap potensi manusia, sehingga memiliki kepribadian dan akhlak yang baik, serta berdampak baik bagi alam dan masyarakat. Pendidikan karakter juga dapat diartikan sebagai proses bimbingan yang membantu menumbuhkan, mengembangkan, mendewasakan, dan membentuk kepribadian seseorang yang merupakan sifat atau karakter seseorang (Shenfield, 2016, Putra, 2017; White \& Shin, 2017). 
Salah satu cara yang ditempuh untuk mewujudkan hal tersebut adalah melalui lembaga pendidikan khususnya sekolah. Sekolah adalah lembaga pendidikan formal yang diharapkan dapat memenuhi target-target akademis dan menerapkan urgensi pendidikan karakter. Sekolah terdiri berbagai tingkatan, baik itu Taman Kanak-kanak, Sekolah Dasar, Sekolah Menengah Pertama, Sekolah Menengah Atas, Perguruan Tinggi dan sekolah-sekolah lain yang memiliki tingkatan masing-masing yang sederajat (Permendikbud, 2019). Sekolah Dasar (SD) merupakan salah satu sekolah reguler dan merupakan dasar untuk studi selanjutnya. Implementasi pendidikan karakter di sekolah dasar dapat dimasukkan ke dalam proses pembelajaran seperti berbagai mata pelajaran yang bersentuhan langsung dengan agama atau materi pendidikan (Julaiha, 2014). Salah satu mata pelajaran yang dapat memberikan penanaman karakter adalah Pendidikan Kewarganegaraan. Pendidikan kewarganegaraan (PKn) pada hakikatnya merupakan program pendidikan yang memiliki pembahasan tentang kebangsaan, masalah kewarganegaraan yang berkaitan dengan negara, demokrasi, hak asasi manusia dan masyarakat sipil, serta menerapkan prinsip demokrasi dan pendidikan humanistik (Dianti, 2014; Juliardi, 2015). Pandangan lain mengatakan bahwa pendidikan kewarganegaraan bertujuan untuk mengingatkan warga negara akan pentingnya nilai, hak dan kewajiban, agar segala sesuatu yang dilakukan sejalan dengan tujuan dan cita-cita negara serta tidak menyimpang dari harapan (Swalwell, 2015; Llano, 2017; Ngozwana, 2017).

Namun dalam proses pelaksanaannya, mata pelajaran PKn menghadapi beberapa kendala yaitu dianggap kurang menarik, sepele, membosankan, berpusat pada guru, banyak ceramah, pengembangan budaya menghapal, pengajaran berbasis buku teks, dan dan posisi guru yang masih mentransfer pengetahuan dan emosi/sikap siswa yang berkaitan dengan proses pembentukan kepribadian sering terabaikan (Setiawan, 2014). Oleh karena itu, pembelajaran PKn ini perlu ditingkatkan dengan mengembangkan karakter siswa mulai dari perencanaan, proses/pelaksanaan, evaluasi, dan kendala yang akan dialami. Telah banyak penelitian mengenai pendidikan kewarganegaraan sebagai pendidikan karakter di sekolah (Kurniawan, 2013; Karimah, 2015; Suardi, dkk, 2019). Selanjutnya untuk konsep pendidikan karakter telah ada beberapa penelitian (Cahyono, 2015; Nastiti, 2017; Sugiana, 2019). Penelitian tersebut telah dilaksanakan pada jenjang menengah ke atas. Pada jenjang universitas, terdapat beberapa penelitain juga mengenai pendidikan kewarganegaraan sebagai pendidikan karakter Tinggi (Dhiu \& Bate, 2017; Mansir, 2017; Hidayah, Ulfah, \& Suyitno, 2019). Berdasarkan berbagai permasalahan yang telah dibahas pada paragraf sebelumnya, maka penulis mencoba menelusuri akar permasalahan yang saat ini terjadi, khususnya dalam penyelenggaraan pendidikan kewarganegaraan sebagai pendidikan karakter di persekolahan. 


\section{METODE PENELITIAN}

Penelitian ini akan menggunakan metode penelitian kualitatif untuk mengungkap secara jelas fakta-fakta tentang fenomena yang terjadi di lapangan, kemudian melakukan analisis mendalam terhadap hasilnya. Penelitian kualitatif bertujuan untuk memahami fenomena yang dialami oleh objek penelitian secara komprehensif, seperti persepsi, motivasi, tindakan diri, dan deskripsi melalui bahasa dan bentuk bahasa melalui penggunaan konteks alam khusus dan berbagai metode ilmiah (Moleong, 2007, hlm. 6). Rancangan penelitian dalam penelitian ini adalah melalui studi kasus. Para partisipan dalam penelitian ini terdiri dari guru Pkn dan siswa. Peneliti memilih partisipan tersebut berdasarkan pemahaman mereka terhadap masalah dalam penelitian yang sedang dilakukan. Tempat penelitian dilakukan di SDN 077 Sejahtera Sukajadi, Kota Bandung. Jenis data yang diungkapkan dalam penelitian ini bersifat naratif, data partisipan dideskripsikan dan dijelaskan dalam bentuk data dokumen lisan dan tertulis, serta perilaku partisipan yang diamati langsung di tempat juga menjadi data untuk mengumpulkan hasil penelitian ini. Adapun langkah-langkah pelaksanaan penelitian adalah mengumpulkan data wawancara dari narasumber yang kemudian diolah, hasil observasi pengamatan di lapangan, pengumpulan dokumen yang berhubungan dengan pendidikan karakter melalui mata pelajaran PKn di sekolah. Kemudian melakukan pengumpulan data keseluruhan dengan membuat gambaran-gambaran data dan langkah selanjutnya melakukan analisis data yang telah terkumpulkan.

\section{HASIL DAN PEMBAHASAN}

Mata pelajaran PKn sebenarnya merupakan salah satu mata pelajaran yang memiliki banyak nilai-nilai karakter karena mata pelajaran ini merupakan salah satu sektor utama dalam penanaman pendidikan karakter. Tetapi pada kenyataannya PKn kurang dianggap penting, karena dianggap memiliki banyak materi hapalan dan tidak dapat menjalankan fungsinya sebagai sektor utama dari pendidikan karakter. Padahal, di dalam PKn ini terdapat dua nilai karakter penting yaitu nilai karakter pokok dan nilai karakter utama. Nilai karakter pokok bertujuan menciptakan siswa yang religius, jujur, cerdas, tangguh, demokratis, dan peduli. Sedangkan nilai karakter utama bertujuan menciptakan siswa yang nasionalis, patuh pada aturan sosial, menghargai keberagaman, sadar akan hak dan kewajiban diri dan orang lain, bertanggung jawab, berpikir logis, kritis, kreatif, dan inovatif, dan mandiri (Juliardi, 2015). Listyarti (2012, hlm. 5-8) mengatakan bahwa ada 18 nilai karakter bangsa yang harus disisipkan dalam pendidikan yaitu religius, jujur, toleransi, disiplin, kerja keras, kreatif, mandiri, demokratis, rasa ingin tahu, semangat kebangsaan, cinta tanah air, menghargai prestasi, bersahabat/komunikatif, cinta damai, gemar membaca, 
peduli lingkungan, peduli sosial, dan tanggung jawab. Oleh karena itu, peneliti melakukan rangkaian kegiatan yang memungkinkan mata pelajaran PKn untuk menanamkan pendidikan karakter pada peserta didik khususnya karakter religius, semangat kebangsaan, rasa ingin tahu, tanggung jawab, bersahabat/ komunikatif dan kerja keras.

Berdasarkan hasil penelitian, guru SDN 077 Sejahtera mengemukakan bahwa pendidikan karakter adalah pendidikan yang berkaitan dengan sikap dan perilaku siswa agar individu siswa menjadi lebih baik. Hal ini sejalan dengan Kemendikbud (2016) yang mengemukakan bahwa pendidikan karakter merupakan gerakan pendidikan di sekolah yang bertujuan untuk membentuk, mentransformasikan, menyebarkan dan mengembangkan potensi peserta didik dengan cara mengkoordinasikan hati, perasaan, pemikiran dan gerak yang sesuai dengan filsafat hidup dalam Pancasila. Oleh karena itu, sebagai pendidik, guru memiliki kewajiban untuk menanamkan pendidikan karakter pada siswa. Hal ini bisa dimulai dengan memberikan contoh/keteladanan saat kegiatan belajar mengajar di kelas, karena selain mengajar tugas dan kewajiban guru juga harus menjadi panutan dan fasilitator bagi siswa.

Perencanaan implementasi pendidikan kewarganegaraan sebagai pendidikan karakter di SDN 077 Sejahtera khususnya yang dilakukan oleh guru PKn yaitu menyiapkan perencanaan pembelajaran yang terdiri dari program tahunan (prota), program semester (promes), silabus, Rencana Pelaksanaan Pembelajaran (RPP) yang berisi nilai-nilai karakter yang akan dikembangkan. Mulyasa (dalam Dianti, 2014, hlm. 231) menyatakan bahwa perencanaan pembelajaran paling sedikit meliputi tiga kegiatan yaitu penentuan kebutuhan, penentuan kompetensi dan penyusunan rencana pembelajaran. Sedangkan menurut Hamalik (2009, hlm. 50) hal-hal yang harus diperhatikan dalam menyusun RPP adalah:

1. Rencana yang dikembangkan harus menyesuaikan dengan sumber daya yang ada.

2. Organisasi pembelajaran harus selalu memperhatikan situasi di lingkungan sekolah.

3. Guru yang merupakan pengelola pembelajaran harus bertanggung jawab penuh atas tanggung jawab dan fungsinya.

Dalam implementasi pendidikan kewarganegaraan sebagai pendidikan karakter di SDN 077 Sejahtera, perencanaan pembelajaran ini berfungsi untuk menentukan kegiatan yang akan dicapai dan bagaimana cara mencapainya, berapa lama waktu yang dibutuhkan, berapa orang yang akan dibutuhkan, serta apa yang harus selalu persiapkan dalam perencanaan pembelajaran tersebut. Dalam rangka penyusunan silabus dan RPP, pihak sekolah selalu memuat nilainilai, sikap dan perilaku yang dapat memfasilitasi proses pembelajaran dan 
mendorong pembentukan karakter siswa sesuai dengan tujuan pembelajaran yang direncanakan. Tujuan penyusunan RPP dan silabus ini adalah untuk mendorong setiap guru agar mempersiapkan kegiatan belajar mengajar yang dapat membantu membentuk kemampuan dan karakter siswa (Karimah, 2015). Konsep silabus dan RPP berkarakter ini sendiri bertujuan untuk mempermudah kegiatan proses pembelajaran dan membentuk karakter siswa sesuai dengan yang telah direncanakan sebelumnya. Hal ini sejalan dengan pandangan Mulyasa (2011, hlm.83) bahwa tahap perencanaan pendidikan karakter dalam pembelajaran PKn meliputi penyusunan silabus dan RPP, dimana kegiatan tersebut harus mengembangkan sikap, nilai dan perilaku serta dalam menyusun silabus dan RPP ini harus mempermudah proses pembelajaran dalam membentuk karakter peserta didik.

Pada tahap pelaksanaan implementasi pendidikan kewarganegaraan sebagai pendidikan karakter di SDN 077 Sejahtera guru melaksanakan kegaiatan belajar mengajar sesuai dengan RPP berkarakter yang telah dibuat sebelumnya. Pada kegiatan pendahuluan pembelajaran guru selalu melakukan pembiasaan dengan melaksanakan do'a menurut agama masing-masing dan juga menyanyikan lagu Indonesia Raya atau lagu wajib nasional yang lain untuk menanamkan sikap religius dan nasionalime kepada siswa. Nilai karakter religius ini mencerminkan keimanan kepada Tuhan Yang Maha Esa, dimana tercermin dalam tindakan melaksanakan ajaran agamanya (Dewi, Suresman, \& Mustikasari, 2020). Sedangkan nilai karakter nasionalisme/semangat kebangsaan mencerminkan sikap atau tindakan dalam melindungi dan menjaga bangsa serta menempatkan kepentingan bangsa dan negara diatas kepentingan pribadi atau kelompok (Annisa, Hasibuan, \& Siregar, 2020). Kemudian, guru juga memberikan contoh/ keteladanan dengan datang mengajar tepat waktu, berpakaian rapi dan sopan saat mengajar di kelas, serta memperhatikan kerapihan kelas. Keteladanan ini sangat penting dan memiliki kontribusi besar bagi pendidikan serta pembentukan karakter, karena mengedepankan semua aspek perilaku dalam bentuk tindakan praktis, bukan sekedar berbicara (Prasetyo \& Marzuki, 2016). Oleh karena itu, keteladanan guru ini menjadi salah satu faktor yang sangat penting demi efektifitas pendidikan karakter di sekolah.

Kegiatan pendahuluan yang dilakukan oleh guru tersebut sudah sesuai dengan standar proses seperti yang dikemukakan oleh Gunawan (dalam Dianti, 2014, hlm. 66), yaitu:

1. Guru harus mempersiapkan mental dan fisik siswa untuk mengikuti proses pembelajaran. Persiapan mental yang dilakukan oleh guru dapat dimulai dengan berdoa, menanyakan kabar siswa, kesiapan siswa untuk memulai pelajaran, dan lain-lain. Sedangkan persiapan fisik dapat dilakukan dengan mengkondisikan situasi kelas. 
2. Mengajukan pertanyaan yang menghubungkan pengetahuan awal dengan materi yang akan dipelajari, atau biasa disebut apersepsi.

3. Menjelaskan kepada siswa mengenai tujuan pembelajaran atau kompetensi dasar yang akan dicapai dalam kegiatan pembelajaran.

4. Menyampaikan kepada siswa mengenai ruang lingkup bahan ajar, dan menjelaskan deskripsi kegiatan sesuai silabus.

Selanjutnya, guru juga menggunakan metode pembelajaran yang tepat untuk menanamkan pendidikan karakter pada siswa. Hal tersebut terlihat pada saat melaksanakan kegiatan belajar mengajar, dimana guru selalu menciptakan suasana belajar melalui langkah-langkah kegiatan belajar mengajar yaitu:

1. Guru memberi siswa stimulus agar mendorong siswa melakukan eksplorasi dengan mengajukan pertanyaan, sehingga memberikan stimulasi melalui keterampilan bertanya.

2. Setelah distimulasi, siswa menerima lembar kerja siswa (LKS) yang diberikan oleh guru, sehingga siswa berkesempatan untuk menemukan masalah melalui diskusi dengan teman, dan hal ini bertujuan untuk menumbuhkan rasa ingin tahu dan tanggung jawab siswa.

3. Siswa mengumpulkan informasi yang relevan untuk membantu mereka menyelesaikan LKS melalui berbagai sumber seperti buku cetak dan internet.

4. Setelah mengumpulkan data, siswa mengolah data yang diperoleh dengan berdiskusi dengan teman dan memilih informasi yang relevan untuk mengisi LKS, lalu mengonfirmasi data yang diperoleh dan menjawab pertanyaan di LKS. Melalui kegiatan tersebut, secara tidak langsung peserta didik akan mengembangkan karakter bersahabat/komunikatif serta kerja keras. Nilai karakter bersahabat/komunikatif mencerminkan kemampuan untuk menyampaikan ide/gagasan kepada orang lain sehingga mewujudkan suasana yang menyenangkan ketika bekerjasama (Hanum \& Meilinda, 2019). Sedangkan nilai karakter kerja keras mencerminkan sikap bersungguhsungguh dalam mencapai tujuan, megatasi hambatan dalam penyelesian suatu tugas atau pekerjaan (Wuryanti \& Kartowagiran, 2016).

5. Terakhir, guru meminta masing-masing kelompok untuk menjelaskan hasil diskusi dan menarik kesimpulan tentang materi yang dipelajari bersama.

Tahapan terakhir dalam pembelajaran PKn berkarakter ini, yaitu kegiatan penutup. Pada kegiatan penutup, guru mengintegrasikan nilai-nilai karakter yang sesuai dengan RPP yang telah dipersiapkan sebelumnya. Sehingga, guru melakukan kegiatan penutup dengan baik dan hal ini sangat membantu untuk penaman pendidikan karakter kepada peserta didik.

Selain itu, berdasarkan data yang diperoleh peneliti melalui observasi dan wawancara langsung di lapangan, peneliti menemukan bahwa evaluasi/teknik 
penilaian dalam pembelajaran PKn ini belum beragam. Guru hanya mengevaluasi tugas siswa dalam bentuk tertulis, dan kurang mengevaluasi sikap siswa secara maksimal selama proses pembelajaran. Padahal jika dilihat dari perspektif teori evaluasi pembelajaran, guru dapat mengevaluasi melalui observasi, wawancara, catatan anekdot, skala bertingkat, penilaian diri, penilaian antar teman, dan portofolio (Ratnawulan \& Rusdiana, 2014). Kemudian, pada penelitian ini, peneliti juga menemukan beberapa kendala pada saat pelaksanaan implementasi pendidikan kewarganegaraan sebagai pendidikan karakter di SDN 077 Sejahtera. Kendala pertama adalah terkadang kegiatan mengajar terlalu cepat, sehingga penilaian sikap siswa kurang optimal dilaksanakan. Solusinya adalah menyelesaikan masalah waktu sehingga guru dapat mengevaluasi sikap terhadap siswa secara maksimal. Kendala kedua adalah kurangnya pendidikan karakter dalam keluarga, sehingga pendidikan karakter di sekolah belum optimal. Solusi yang ditempuh adalah sekolah memberikan kesempatan kepada anak untuk mendapatkan pendidikan karakter di rumah pada saat weekend yaitu hari sabtu dan minggu. Selain itu, pihak sekolah juga mengajak para orang tua siswa untuk saling bertukar informasi tentang pengetahuan terkait pendidikan karakter yang dijalankan sekolah, agar orang tua dapat berpartisipasi dalam memberikan pendidikan karakter kepada anaknya.

\section{PENUTUP}

Berdasarkan hasil penelitian dan pembahasan sebelumnya, maka diperoleh beberapa kesimpulan yaitu perencanaan implementasi pendidikan keawarganegaraan sebagai pendidikan karakter di persekolahan khususnya di SDN 077 Sejahtera yaitu dalam perencanaan pembelajaran dilakukan pemasukan nilai-nilai karakter yang dikembangkan dalam RPP serta langsung menambahkannya ke dalam kegiatan pembelajaran, dimana hal ini dilakukan melalui modifikasi RPP karakter berdasarkan jenis karakter yang ingin dicapai. Kemudian pelaksanaan implementasi pendidikan kewarganegaraan sebagai pendidikan karakter di persekolahan khususnya di SDN 077 Sejahtera yaitu dengan menerapkan dan menggunakan berbagai metode dan sumber belajar, serta memasukkan berbagai karakter ke dalam kegiatan pembelajaran, seperti religius saat beribadah, semangat kebangsaan saat menyanykan berbagai lagu wajib nasional, mengembangkan rasa ingin dan tanggung jawab saat berdiskusi, dan bersahabat/komunikatif dan kerja keras untuk menemukan semua jenis informasi. Evaluasi implementasi pendidikan kewarganegaraan sebagai pendidikan karakter di persekolahan khususnya di SDN 077 Sejahtera yaitu guru telah melakukan berbagai penilaian seperti tes tulis, tetapi masih kurang maksimal ketika melakukan penilaian terhadap sikap peserta didik selama proses pembelajaran. Kendala implementasi pendidikan kewarganegaraan sebagai 
pendidikan karakter di persekolahan khususnya di SDN 077 Sejahtera adalah waktu pembelajaran dianggap sangat cepat, sehingga penilaian terhadap sikap siswa kurang optimal, dan pendidikan karakter dirumah yang kurang, sehingga pendidikan karakter di sekolah juga kurang optimal. 


\section{DAFTAR PUSTAKA}

Annisa, N., Hasibuan, P. H., \& Siregar, E. F. S. (2020). Menyanyikan Lagu Indonesia Raya sebagai bentuk Impelementasi Penguatan Pendidikan Karakter di SDS Asuhan Jaya Kota Medan. Jurnal Benderang, 1(1), 1-5.

BSNP. (2010). Laporan BSNP Tahun 2010. Jakarta: Badan Standar Nasional Pendidikan.

Cahyono, H. (2015). Pola Pengembangan Pendidikan Karakter Siswa. Jurnal Dimensi Pendidikan dan Pembelajaran, 3(2), 5-12.

Dewi, R. R., Suresman, E., \& Mustikasari, L. (2020). Implementasi Kebijakan Mata Kuliah Pendidikan Kewarganegaraan Sebagai Pendidikan Karakter di Perguruan Tinggi. Jurnal Edueksos (The journal of social and economics education), IX(1), 1-15.

Dianti, P. (2014). Integrasi Pendidikan Karakter dalam Pembelajaran Pendidikan Kewarganegaraan untuk Mengembangkan Karakter Siswa. JPIS (Jurnal Pendidikan Ilmu Sosial), 23(1), 58-68.

Dhiu, K. D.,\& Bate, N. 2017. Pentingnya Pendidikan Karakter di Perguruan Tinggi: Kajian Teoritis Praktis: 2nd Annual Proceesding, STKIP Citra Bakti Bajawa NTT, 172-176.

Hamalik, O. (2009). Perencanaan Pengajaran Berdasarkan Pendekatan Sistem. Jakarta: PT Bumi Aksara.

Hanum, A., \& Meilinda, A. (2019). Studi Karakterisasi Bersahabat/Komunikatif Pada Siswa SMPN 18 Kota Jambi. Jurnal Publikasi Pendidikan, 9(2), 147151.

Haryanto, R. (2019). Tranformasi Pendidikan Abad 21 Melalui Rumah Belajar. [Online]. Tersedia di http://pena.belajar.kemdikbud.go.id/2019/07/ tranformasi-pendidikan-abad-21-melalui-rumah-belajar/. Diakses pada 30 Mei 2020.

Hidayah, Y., Ulfah, N., \& Suyitno. (2019). Pendekatan Pembelajaran Mata Kuliah Wajib Umum Pancasila dan Pendidikan Kewarganegaraan di Perguruan Tinggi. Jurnal Pancasila dan Kewarganegaraan, 4(1), 22-33. 
Julaiha, S. (2014). Implementasi Pendidikan Karakter DalamPembelajaran. Dinamika Ilmu, 14(2), 226-238.

Juliardi, B. (2015). Implementasi Pendidikan KarakterMelalui Pendidikan Kewarganegaraan. JURNAL BHINNEKA TUNGGAL IKA, 2(2), 119-126.

Karimah, M. (2015). Implementasi Pendidikan Karakter Dalam Pembelajaran Pendidikan Kewarganegaraan Di Madrasah Salafiyah Ibtidaiyah. IJCETS (Indonesian Journal of Curriculum and Educational Technology Studies), 3(1), 49-55.

Kemendikbud. (2016). Konsep dan Pedoman Penguatan Pendidikan Karakter. Jakarta: Kementerian Pendidikan dan Kebudayaan.

Kurniawan, M. I. (2013). Integrasi Pendidikan Karakter ke dalam Pembelajaran Kewarganegaraan di Sekolah Dasar. Jurnal Pemikiran dan Pengembangan SD, Jilid 1, No. 1, 37-45.

Lickona, T. (2012). Character Matters. Jakarta: PT Bumi Aksara.

Llano, S. M. (2017). The counterfeit presentment: an early 20th century model of intercollegiate debate as civic education. Argumentation and Advocacy, 53(2), 90-102. http://dx.doi.org/10.1080/00028533.2017.1304983.

Listyarti, R. (2012). Pendidikan Karakter dalam Metode Aktif, Inovatif, \& Kreatif. Jakarta: Esensi.

Lydiasari, P. (2018). Sistem Pendidikan di Indonesia Belum Siap Hadapi Abad 21. [Online].Tersedia di https://www.suaramerdeka.com/news/baca/128753/ sistem-pendidikan-di-indonesia-belum-siap-hadapi-abad-21. Diakses pada 30 Mei 2020.

Mansir, F. (2017). Model Pendidikan Karakter di Perguruan Tinggi Islam. (Disertasi). SPS UIN Syarief Hidayatullah Jakarta.

Moleong, L., J. (2007). Metodologi Penelitian Kualitatif. Edisi Revisi. Bandung: PT Remaja Rosdakarya.

Mulyasa. (2011). Manajemen Pendidikan Karakter. Jakarta: Bumi Aksara.

Nastiti, D. (2017). Implementasi Karakter Tanggung Jawab dalam Pembelajaran PPKn melalui Model STAD berbasis Joyfull Learning: Prosiding Konferensi Nasional Kewarganegaraan III, Universitas Ahmad Dahlan, Yogyakarta, 209-213. 
Sugiana, A. (2019). Penanaman Nilai Karakter Disiplin dan Tanggung Jawab di SMK Ethika Palembang. Jurnal PAI Raden Fatah, 1(1), 105-116.

Ngozwana, N. A. (2017). Civic education in Lesotho: implications for teaching of democratic Citizenship. International Journal of Lifelong Education, 36(5), 526-540. https://doi.org/10.1080/02601370.2017.1304460.

Nuraini, R. 2019. Dirjen Pendis: Pendidikan Karakter Tantangan Abad 21 dan Kuncinya Guru. [Online].Tersedia di https://jpp.go.id/humaniora/sosialbudaya/336107-dirjen-pendis-pendidikan-karakter-tantangan-abad-21-dankuncinya-guru. Diakses pada 30 Mei 2020.

Permendikbud. (2019). Pedoman Organisasi dan Tata Kerja Satuan Pendidikan Dasar dan Menengah. Jakarta: Kementrian Pendidikan dan Kebudayaan.

Prasetyo, D.,\& Marzuki. (2016). Pembinaan Karakter melalui Keteladanan Guru Pendidikan Kewarganegaraan di Sekolah Islam Al Azhar Yogyakarta. Jurnal Pendidikan Karakter, Tahun VI, Nomor 2, 215-231.

Putra, P. (2017). Implementasi Pendidikan Karakter dalam Pembelajaran IPA di MIN Pemangkat Kabupaten Sambas Kalimantan Barat. Jurnal Ilmiah PGMI, 3(1), 49-61.

Ratnawulan, E., \& Rusdiana, A. (2014). Evaluasi Pembelajaran. Bandung: Pustaka Setia.

Sauri, S., \& Budimansyah, D. (2014). Nilai kearifan Lokal Pesantren Lokal Pesantren dalam Upaya Pembinaan Karakter Santri. NIZHAM, 3(02), 21 50.

Sauri, S., \& Nurdin, D. (2019). Manajemen Pendidikan Berbasis Nilai. Cetakan Kesatu. Bandung: Refika Aditama.

Setiawan, D. (2014). Pendidikan Kewarganegaraan Berbasis Karakter melalui Penerapan Pendekatan Pembelajaran Aktif, Kreatif, Efektif dan Menyenangkan. Jurnal Pendidikan Ilmu-Ilmu Sosial, 6(2), 61-72.

Suardi, dkk. (2019). Implementasi Pendidikan Karakter Melalui Mata Pelajaran Pendidikan Kewarganegaraan di SMA Jaya Negara Makassar. Jurnal Etika Demokrasi, 4(1), 22-29.

Swalwell, K. (2015). Mind the civic empowerment gap: Economically elite students and critical civic education. Curriculum Inquiry, 45(5), 491-512. https://doi.org/10.1080/03626784.2015.1095624. 
84 Rinita Rosalinda Dewi dkk, Pendidikan Kewarganegaraan

Wahyu. (2011). Masalah dan Usaha Membangun Karakter Bangsa. Jurnal Komunitas, 3(2), 138-149.

Wuryanti, U., \& Kartowagiran, B. (2016). Pengembangan Media Video Animasi Untuk Meningkatkan Motivasi Belajar Dan Karakter Kerja Keras Siswa Sekolah Dasar. Jurnal Pendidikan Karakter, VI(2), 232-245.

Zakiyah, Q.Y., \& Rusdiana. (2014). Pendidikan Nilai: Kajian Teori dan Praktik di Sekolah. Bandung: CV Pustaka setia. 